\title{
PREDICTORS OF POLITICAL ACTIVISM AMONG SOCIAL WORK STUDENTS
}

\author{
Eric W. Swank
}

Morehead State University

\begin{abstract}
This article identifies factors inspiring greater political participation among undergraduate social work students $(N=125)$. When separating students into self-identified liberals and conservatives, the study uses resource, mobilizing, and framing variables to explain greater levels of activism. After several multivariate regressions, this article concludes that political activism is spurred by many motivators. For liberals and conservatives, belonging to an activist network and maintaining activist identities were crucial to different modes of activism. Moreover, the perceived legitimacy of traditional institutions predicted protest actions of liberals and conservatives, whereas notions of collective efficacy influenced only electoral activism. Finally, demographic status mattered only for conservative students, as female and African American conservatives were less likely to protest than male and Euro American conservatives.
\end{abstract}

WHEN CONTESTING CULTURAL prejudices and structural inequalities, much of social work practice has a political nature. Social workers can try to change institutional causes of poverty, homelessness, drug abuse, sexual violence, heterosexism, and other social ills by entering the political process that creates and implements detrimental policies. As such, professional organizations urge political participation for social workers. The preamble for the 2008 National Association of Social Workers (NASW) Code of Ethics reads: "Social workers promote social justice and social change with and on the behalf of clients." Several practices accomplish this, including "direct practice, community organizing, social and political activism" (NASW, 2008). To prepare future professionals, the Council on Social Work Education (CSWE) in their accreditation standards insists that social work programs should foster a commitment to political action by including content on "social or political action" (CSWE, 2001, B4.1.3, M4.1.3). Other organizations also base their entire missions around politically mobilizing social workers (e.g., Social Welfare Action Alliance, Influencing State Policy). 
Although political activism has always been a part of social work practice, scholars believe that the extent of social worker activism has ebbed and flowed throughout history (Mullalay, 1993). Since the beginning of the Reagan administration, commentators have warned that the social work profession has become too micro oriented and has neglected its activist mission (Abramowitz, 1998; Fisher, 1995; Specht \& Courtney, 1993).

Such debates flourish in discussions of social work students as well. One study contends that a "desire to create social change" is a major motive for students choosing social work (Hanson \& McCullagh, 1995, p. 35), whereas two other studies suggest that social work students are not enamored with political activism and prefer a career in micro practice (Aviram \& Katan, 1991; Butler, 1990). On top of contradictory descriptive findings, only a few multivariate studies try to explain why social work students would be politically active. The current study extends this literature by examining the political actions of students in bachelor's of social work (BSW) programs. In doing so, this article tries to identify the factors that differentiate the politically active from the politically lethargic. With a focus on factors that may inspire and hinder activism, this work integrates insights from many academic disciplines. The much-cited resource model of political science guides this study's theoretical conceptualizations (Brady, Verba, \& Scholzman, 1995) as do the sociological theories of "mobilization structures" (McAdam \& Paulsen, 1993; McCarthy, 1996; Passy, 2001) and "collective action frames" (Gamson, 1992; Klandermans, 1997; Snow \&
Benford, 1992). This work also taps the nascent literature on activism among social work students (Aviram \& Katan, 1991; Butler, 1990; Rocha, 2000; Swank \& Fahs, 2011; Weiss, 2003) and employed social workers (e.g., Dudziak \& Coates, 2004; Ezell, 1993; Hamilton \& Fauri, 2001; Parker \& Sherraden, 1992; Reeser, 1992; Ritter, 2008; Wolk, 1981).

When addressing these debates and gaps within the empirical literature, this study asks two research questions: First, how politically active are undergraduate social worker students? Second, what factors foster greater political activism among undergraduate social work students?

\section{Literature Review}

Variable selection in this study is partially guided by the "resource model" of political participation (Brady et al., 1995). Offering a succinct answer as to why people refrain from politics, the resource model asserts: "because they can't, because they don't want to, or because nobody asked" (Brady et al., 1995, p. 271). "They can't" suggests a dearth of necessary resources to be political. Although crucial resources may come in many forms, these authors emphasize the importance of financial situations, free time, and civic skills. "They don't want to" deals with a lack of psychological engagement in politics. This indifference to politics is sometimes seen as political ignorance, but the resource model assumes that this is a reaction to a lower sense of political efficacy and greater levels of individualism. "Nobody asked" implies that people are isolated from the recruitment networks that move citizens into action. 


\section{They Can't: Class, Race, and} Gender Gaps

According to the authors of the resource model (Brady et al., 1995), socioeconomic standing (SES) is a powerful variable that drives political participation for members of every social group in society (e.g., SES works across race, gender, and occupational boundaries). In the simplest of terms, a person's class location grants or impedes access to opportunities and financial resources that make political activism easier.

Numerous studies argue that affluence predicts political activism in samples of the general public (Barkan, Cohn, \& Whitaker, 1995; Brady et al., 1995; Leighley \& Vedlitz, 1999; Oliver, 1984; Tate, 1991; Wallace \& Jenkins, 1995) and collegiate undergraduates (Dey, 1997; Paulsen, 1994). When examining social workers, the impact of income on activism is less clear. A few studies argue that social workers are more political when they have higher incomes and more financial assets (Parker \& Sherraden, 1992; Wolk, 1981). Other studies, however, find no such relationship (Andrews, 1998; Ezell, 1993; Hamilton \& Fauri, 2001; Ritter, 2008).

The resource model also asserts that educational attainment leads to greater political engagement. A set of general population studies connects greater educational attainment to greater levels of electoral and protest activism (Finkel \& Muller, 1998; Kingston \& Finkel, 1987; Leighley \& Vedlitz, 1999; Lim, 2008; Wallace \& Jenkins, 1995). Studies among social workers often highlight the effects of education. Higher levels of educational attainment seem to inspire greater levels of activism among practicing social workers (Andrews, 1998; Chui \& Gray, 2004; Ezell, 1993; Parker \& Sherraden, 1992; Wolk, 1981). Among social work students, it is possible that the completion of certain classes makes students more politically active (Rocha, 2000; Swank \& Fahs, 2011; Van Soest, 1996; Van Voorhis \& Hostetter, 2006). However, Van Soest (1996) cautioned that finishing a class on oppression did not lead to higher advocacy intentions, and Weiss and Kaufman (2006) noted that BSW students were less willing to engage in social action after they did a field placement in organizations that emphasized political change. Finally, educational attainment measures were insignificant in the most comprehensive multivariate study on social worker political participation (Ritter, 2008).

Previous studies have sometimes found links between political participation and one's gender and race background. For example, African American high school and college students protested more regularly than Euro American students in the 1970s (Paulsen, 1994) and in the 1990s (Dolan, 1995). Social work studies have occasionally confirmed this pattern. Two studies found that African American social workers and MSW students wrote more letters to Congress, attended more political meetings, and joined more community organizing efforts than White Euro Americans with lesser academic degrees (Ezell, 1993; Rocha, 2000). Nevertheless, four studies argued that race background of respondents was irrelevant when addressing the electoral activities of social workers (Andrews, 1998; Parker \& Sherraden, 1992; Ritter, 2008; Wolk, 1981). 
The relationship between gender status and political participation is far from certain. Some studies suggest that up until the 1970s women were slightly less likely to vote or join political protests (Barkan et al., 1995; Kingston \& Finkel, 1987; Wallace \& Jenkins, 1995). Conversely, studies on contemporary populations suggest that this gender gap has disappeared or has even been reversed (Bean, 1991; Eckberg, 1988; Hritzuk \& Park, 2000; Leighley \& Nagler, 1992; Paulsen, 1994; Schussman \& Soule, 2005; Tate, 1991). Studies on a political action gender gap among social workers were more conclusive. Only one study of social workers in Hong Kong found that male respondents were more politically active (Chui \& Gray, 2004). In every other study, gender failed to predict the political engagement of social workers (Andrews, 1998; Ritter, 2008; Rocha, 2000; Wolk, 1981).

Transition into marriage or divorce can influence a person's political activities (Fahs, 2007; Stoker \& Jennings, 1995). The early stages of marriage can suppress political engagement for both men and women (Cole, Zucker, \& Ostrove, 1998; Kingston \& Finkel, 1987; Opp, 1990; Stoker \& Jennings, 1995), whereas other studies contend that long-term married people were more likely to vote (Leighley \& Vedlitz, 1999). Ending marriages can also politicize women because divorced women are more likely to engage in feminist activism (Cole et al., 1998; Fahs, 2007). Conversely, some studies concluded that marital status was a poor predictor of political practices (Dolan, 1995; Hritzuk \& Park, 2000; Paulsen, 1994; Schussman \& Soule, 2005).

Living in large metropolitan centers can sometimes inspire more activism (Bean, 1991).
For example, urban African Americans were more likely to join the civil rights movement (Beyerlein \& Andrews, 2008) or vote in the 1980s (Tate, 1991). Among social workers, urban social workers were more politically active than their rural counterparts (Ritter, 2008).

\section{They Don't Want To: Framing Grievances, Efficacy, and Collective Identities}

Frames are generally conceived as cultural tools or schemas that provide "tacit theories about what exists, what happens, and what matters" (Gitlin, 1980, p. 6). Although frames help with the classification and organization of incoming stimuli, they also serve a political function. Conventional frames acquire the consent of subordinates by portraying the social order as proper, normal, and inevitable. By seeking widespread conformity, mainstream narratives get people to subscribe to values, ideals, and self-definitions that bind them to their social location. Collective action frames are the set of beliefs that motivate people into joining collective efforts that publicly seek social change.

Movement theorists have identified several dimensions of collective action frames (Ashmore, Deaux, \& McLaughlin-Volpe, 2004; Gamson, 1992; Klandermans, 1997). First, collective action frames initially reinterpret some societal norms as wrong, unacceptable, and unjust. Second, frames identify the causes of the injustice. By serving as a diagnostic function, frames are etiologies that explain why problems exist and assign levels of blame or culpability to different entities. Third, frames 
also convince bystanders that they should use political tactics to stop these violations. This prognostic aspect of frames usually emphasizes the urgency of political action and a sense that challenges from less powerful constituencies can force concessions from a reluctant target (this is sometimes referred to as agency or a sense of collective efficacy). Finally, frames must provide a collective or shared identity among the aggrieved. In doing so, collective identities establish social boundaries between "us" and "them" by specifying who belongs to the righteous in-group of the mistreated and who represents the antagonistic wrongdoers who must be mobilized against. These collective identities often contest and refute societal claims that members of their group are inferior, worthless, sick, or maladjusted. Instead, collective action frames offer narratives about the virtues of similar people and claim that their group is illegitimately threatened, deprived, or mistreated.

Numerous studies concur that injustice frames are relevant to joining social movements (Finkel \& Muller, 1998). Feminist activism occurred more often when women noticed power imbalances between men and women (Cole et al., 1998; Kelly \& Breilinger, 1995), whereas civil rights activism was more common when African Americans saw systematic forms of racial discrimination (Beyerlein \& Andrews, 2008; Tate, 1991). Antinuclear activists believed that atomic energy was dangerous (Opp, 1990), antiwar activists saw foreign policy as immoral (Swank \& Fahs, 2011; Wood \& Ng, 1980), hunger activists saw structural causes for starvation (Barkan et al., 1995), and students who recognized discrimi- natory marriage laws were more likely to protest for gay and lesbian rights (Simon, Lowry, Sturmer, Weber, \& Freitag, 1998).

Social work research on political participation has mostly ignored the role of injustice frames. Two rare studies found that MSW students who believed in a just world advocated for women, people of color, and homosexuals less often (Van Soest, 1996; Van Voorhis \& Hostetter, 2006). Moreover, Israeli BSW students endorsed political activism more freely when they saw poverty emanating from a lack of jobs and discrimination (Weiss, 2003), and antiwar activism was more common among U.S. social work students when they doubted American efforts at spreading democracy throughout the world (Swank \& Fahs, 2011).

Although perceptions of social biases and discrimination offer an impetus for political activism, these thoughts by themselves do not guarantee that political action will occur. People who see unfair practices may be resigned to endure or cooperate with oppressive institutions when they think the status quo is unable to be changed or altered by nonelites. Accordingly, some argue that sympathetic bystanders must feel that their contributions will add to a movement's success before they join a political movement.

To date, the role of power interpretations in political activism is far from settled. Some works contend that perceptions of personal efficacy (Hritzuk \& Park, 2000; Leighley \& Vedlitz, 1999; Lim, 2008) and collective efficacy are crucial to activism (Barkan et al., 1995; Beyerlein \& Andrews, 2008). Accordingly, it has been found that college students are more likely to be politically active when they think 
that the government is responsive to citizen demands (Dolan, 1995), and women were more likely join feminist mobilizations when they felt that they had a firm grasp of political affairs and when they thought the women's movement was powerful (Cole et al., 1998). Conversely, some studies insist that a sense of efficacy has little to do with participation in the women's movement (Kelly \& Breilinger, 1995), liberal activism (Schussman \& Soule, 2005), antinuclear protests (Opp, 1990), and youth movements (Bean, 1991; Paulsen, 1994).

The occasional social work activism studies have found credence in the efficacy hypothesis (Ritter, 2008; Swank \& Fahs, 2011). Hamilton and Fauri (2001) discovered that politically engaged social workers expressed more political efficacy; Pawlack and Flynn (1990) noted that social work administrators refrained from political activism when they believed that their activism could lead to negative repercussions for themselves or their agency.

Issues of collective identities and self concepts can change a person's political behaviors in many ways. Advocacy on behalf of oneself and others is often interwoven with issues of self-conceptions and moral obligations. Accordingly, activist identities were often connected to narratives of how to display a desired or idealized self and how to live a principled life (Kelly \& Breilinger, 1995; Oliver, 1984; Opp, 1990; Polleta \& Jasper, 2001). To people who internalize activist identities, political engagement is an opportunity to express key moral convictions and to act upon obligations of reciprocity, fairness, and concern for the common good.
Empirical studies have noted that the purposive incentives of adhering to moral codes and the commitment to social justice were strong predictors of antinuclear activism in Germany (Opp, 1990), feminist activism in Britain (Kelly \& Breilinger, 1995), and peace activism in the United States (Swank, 1994). In studies of social workers, ethical reasons for activism were especially important (Swank \& Fahs, 2011). A study of Israeli social work students discovered a greater willingness to be politically involved when the students saw a congruency between social work and social action (Weiss \& Kaufman, 2006). Similarly, one study found higher political participation among professors who thought social work was "inherently political" and that it is an ethical responsibility to engage in political activities (Mary, 2001); another found that agency directors were less politically active when they thought such actions were inappropriate for a person in their profession (Pawlak \& Flynn, 1990). Finally, Reeser (1992) discovered that social workers whose primary loyalty was with clients were more committed to social action than employees who voiced a stronger loyalty to their agency's rules and regulations.

\section{Nobody Asked: Social Networks and Mobilizing Structures}

Theories about mobilizing structures suggest that residing in certain social environments fosters greater political activism (McAdam \& Paulsen, 1993; McCarthy, 1996; Passy, 2001; Polleta and Jasper, 2001). Social networks, which represent webs of recurring interactions among people and groups, always convey some sort of beliefs, values, norms, and 
identities. Most people derive their worldviews and identities through institutions and networks that praise prevailing social orders, but some networks carry messages that political challenges are necessary, important, and worthwhile.

The proposition that social networks shape political behaviors has drawn considerable interest in movement and participation studies (Cole et al., 1998; Finkel \& Muller, 1998; Lim, 2008; Tate, 1991). Many sorts of contextual and institutional settings can make people predisposed or receptive to political activism. The messages received in familial and peer groupings can have a major impact on political inclinations (Chorn-Dunham \& Bengston, 1992; Dolan, 1995). Accordingly, studies of the general population suggest that citizens are more likely to be antinuclear, civil rights, and gay rights activists when they think that their friends and acquaintances approve of such actions (Beyerlein \& Andrews, 2008; Opp, 1990; Simon et al., 1998). Such associations may be linked to the emotional rewards of adhering to the directives of significant others who encourage political engagement.

Although general population studies often discover a link between referent attitudes and political activism, this has not always been the case in studies on social work activism. Some studies confirm the socialization argument. Recently, Ritter (2008) and Chui and Gray (2004) concluded that social workers were more engaged in activism when they discussed politics with colleagues and family members. Similarly, in a study of peace activism among social work students, Swank and Fahs (2011) discovered a connection between having liberal friends and protesting wars. Nevertheless, other studies yielded contradictory results. Ezell (1993) and Hamilton and Fauri (2001) found no relationship among the frequency of political conversations with one's coworkers, one's family of origin, and the amount of political activism among employed social workers.

Although social networks often encourage the acceptance or rejection of specific collective action frames, they also serve as conduits of important information about political events. Political parties, committed partisans, and movement activists often try to motivate activism through different persuasive techniques (e.g., face-to-face conversations, phone calls, e-mail, direct mail, etc.). Although each recruitment pitch converted some sympathetic bystanders into activists, people were more likely to engage in political actions when they were encouraged or asked to be active by someone whom they personally knew (Finkel \& Muller, 1998; Hritzuk \& Park, 2000; Lim, 2008; McAdam \& Paulsen, 1993; Nepsted \& Smith, 1999; Schussman \& Soule, 2005, Swank \& Fahs, 2011). In fact, a 22-variable study on the general populace found that being asked to participate in a protest was the best predictor of actually appearing in a protest in the last year (Schussman \& Soule, 2005), as did a 17-variable study on licensed social workers (Ritter, 2008).

The following analysis explored the predictive capabilities of resource, framing, and mobilizing variables with regard to political activism among undergraduate social work students. By regressing political behaviors on the 12 variables of family income, education, gender, race, marital status, urbanity, liberal 
mothers, activist friends, activist recruitment networks, liberal injustice frames, activist identities, and perceptions to the data from a multi-college sample, this study identified the factors that distinguished between more or less politically active BSW students.

\section{Method}

\section{Sampling}

This analysis emerged from an original survey of college students (distributed in the fall of 2000). As expected, the study has Institutional Review Board approval and participation was anonymous and voluntary. Although collegiate studies regularly restrict themselves to a single campus, this study randomly selected 12 U.S. colleges. To create a stratified sample, this study initially separated all public campuses into research, doctoral, master's, or baccalaureate clusters (using the Carnegie Classification of Institutions of Higher Education). This creation of four clusters enabled access to students from many types of colleges (from large research campuses to smaller state-run commuter colleges). Next, three schools were randomly selected from each of the four stratums. The schools selected were the University of Delaware, University of Oregon, and University of Texas (research schools); the University of North Carolina-Greensboro, University of Massachusetts Lowell, and Rutgers (doctoral schools); Longwood College, University of Southern Maine, and University of Wisconsin-Green Bay (master's); and Evergreen State College, Mesa State College, and Southeast Arkansas College (baccalaureate).

After selecting these 12 colleges, the author contacted faculty from each institution (via e-mail). Professors in the natural sciences, humanities, social sciences, and business were asked to administer surveys in their classrooms because student attitudes have previously differed by such majors (Astin, 1993). With participation being purely voluntary, 28 of the 338 contacted professors decided to distribute and collect the surveys during one of their class sessions $(8.2 \%)$. Four of these professors taught in BSW programs, and they provided the data for this study.

Clearly this response rate was neither high nor random. Professors who never read e-mail automatically removed themselves from the sample and the willingness to distribute the surveys was not constant throughout the different types of schools and disciplines. For the sample of all professors, around $2 \%$ of the research professors distributed surveys, whereas $13 \%$ of professors at master's-granting universities did so. Likewise, less than $1 \%$ of chemistry, biology, and physics professors assisted in this project whereas professors in political science, sociology, and social work were most receptive to requests for participation $(11 \%)$. Of the social work professors who actually distributed surveys, all taught research.or policy classes.

In total, $125 \mathrm{BSW}$ students completed the survey. As expected, this sample had a high proportion of women ( $89 \%$ female). The sample also had a high percentage of rural residents (i.e., only $24 \%$ of the students claimed to be from large metropolitan areas, $28 \%$ resided in midsize cities, whereas $48 \%$ came from small towns or rural backgrounds). However, the racial breakdown seemed to mirror that of many public institutions- $85 \%$ of the sample was Euro American, $8 \%$ was African Ameri- 
can, $5 \%$ was Latino(a), and less than $1 \%$ were Native or Asian American. Likewise, the age pyramid conformed to familiar trends-the mean age was 26 and $49 \%$ of the students were between 18 and 22 years old (standard deviation equaled 9.5 and the mode was 21 years old). Finally, the social-class composition of the sample was slightly skewed toward lower middle incomes. Twenty-seven percent of the students reported a family income of less than $\$ 20,000$ a year, $31 \%$ had incomes between $\$ 21,000$ and $\$ 40,000,28 \%$ had incomes from $\$ 41,000$ to $\$ 80,000$, and $14 \%$ had family incomes that were more than $\$ 81,000$.

\section{Measures}

The dependent variables focused on the explicit ways in which social workers can influence governmental decisions (Gray, Collett van Rooyen, Rennie, \& Gaha, 2002; Ritter 2008). Individual efforts to change state policies often come through two avenues. One channel is when citizens express their concerns to government leaders through the orthodox or insider avenues of electoral politics. This approach uses institutionalized tactics to shape the legislative process or improve the electability of political candidates (e.g., testifying at legislative hearings, writing letters to Congress, or making political donations to favorite politicians). Compared to other tactics, these approaches take less time and effort and require little risk (Nepstad \& Smith, 1999). By borrowing items from Barnes and Kaase (1979), the electoralinsider tactics scale was comprised of binary questions on petition signing, writing political letters, wearing political buttons, making campaign contributions, or volunteering for political cause. Respondents were asked if they have done these actions throughout their entire lives (with each item having a yes-no format the total scores ranged between 0 and 5). See Table 1 for descriptive data on these items.

Citizens can also draw the attention of authority figures through "outsider" and confrontational means (e.g., engaging in protests, strikes, boycotts, or civil disobedience). As a whole, outsider tactics require greater efforts to join and can be more risky than electoral activism (such activism can lead to arrest or the possibility of being chastised or ridiculed for using unconventional tactics). The composite scale for outsider-militant actions included one item on joining a demonstration and one on engaging in civil disobedience during their lifetime (with each item having a yes-no format the total score ranged between 0 and 2).

Most of the demographic variables were measured through dichotomous dummy variables. For gender, respondents were asked "What is your sex?" (Female=1, Male=0). For marital status, responses were recorded as single or other (Single $=1$, Other $=0$ ). Race was determined by their response to "How would you classify your race/ethnicity?" Although it is often methodologically more sound to identify variance by all races, the small number of Asian, Latino(a), and Native American students led to the binary coding of Whites $=1$ and Others $=0$. To determine urbanness, one question asked: "What is the type of community where you spent most of your youth?" Those who answered "rural" and "small town" were considered rural, whereas the 
answers small, midsize, and large metropoli$\tan$ areas were deemed nonrural (Rural=1, Other $=0$ ).

Some of the other demographic factors were measured through closed-ended scales. Social class was determined through a family income scale (there were 10 categories that started at less than $\$ 10,000$ and ended at more than $\$ 151,000)$. For educational attainment, students were asked, "Please indicate your highest level of education." People who said they were first-year students received a 1 , and senior students were given a 4 .

The concept of mobilizing structures has been operationalized several ways in earlier studies of political participation (most often, studies have explored the value expressed by other people, the way a person was recruited to activism, and types of group affiliations). The variable of Liberal Mother addressed issues of familial political socialization. The political messages of mothers were highlighted because studies suggest that mothers inspire more activism in their children than do fathers or other adult caregivers (ChornDunham \& Bengston, 1992; Wood \& Ng, 1980). The item posed: "My mother can be considered a liberal person" ( $5=$ strongly agree). The Activist Friends measure dealt with the approval of activism among peer referents (see Opp, 1990). The prompt asked respondents if their friends generally condone activism: "Most of my friends think that activism is a positive thing" (5=strongly agree). Activist Networks dealt with the availability of "micromobilization moments" in which bystanders meet political recruiters. To address explicit face-to-face requests for participation, this study asked, "Have any friends ever asked you to go to a political event?" (similar to Eckberg, 1988).

The collective action frames were measured through Likert scales. The three items in the Injustice Framing scale dealt with discontent over the topics of welfare spending, homosexuality, and traditional family values (Cronbach's $\alpha=.643$ ). These topics represent key concerns of the social work profession and most people voice dissatisfaction with specific practices rather than broad condemnations of entire social systems (Finkel \& Muller, 1998; Opp, 1989). The concept of collective efficacy was assessed through interpretation of the potential efficacy of different movement tactics (Finkel \& Mueller, 1998). Four items asked about the how much signature drives, demonstrations, and sit-ins helped the social movement achieve its goals (Cronbach's $\alpha=.650$ ). With codes of "helped a lot" equaling 5 and "hurt a lot" equaling 1 , the total score in this additive scale ranged from 4 to 20 .

The attributes of social identities have often been delineated as an individual's awareness that he or she belongs to a certain social group, together with the evaluative and emotional significance of that membership (Kelly \& Breilinger, 1995). Although closeness to one's social groups can inspire collective action, some studies have suggested that the best predictor of activism was overtly defining oneself as an activist (Kelly \& Breilinger, 1995). Accordingly, activist identities were traced through a 4-item composite scale that dealt with several dimensions of politicized self-concepts (Cronbach's $\alpha=.736$ ). The first two questions of the activist identity scale dealt with the internalization of protest norms 
or the extent to which people felt obliged to protest: "I see myself as someone who is involved in promoting social justice" and "I feel guilty when I am politically active" (Kelly \& Breilinger, 1995; Opp, 1990). Activist identities also compensated for the "free-rider" dilemma of people benefiting from activism even if they remained politically disengaged (Oliver, 1984). Accordingly, one item in the activist identity scale tapped the conviction that respondents are personally active to atone for the political apathy of others: "I must be politically active because most people are politically inactive" ( $5=$ strongly agree). With activist identities concentrating on the need to generate new recruits and political sympathizers, the fourth item of scale read: "I try to initiate political conversations" (5=strongly agree).

\section{Results}

Descriptive statistics for the political participation items are presented in Table 1. Clearly, electoral activism was a preferred form of activism with about three-fourths of the stu- dents signing petitions at least once and between one-third and one-fourth of the students writing a letter, displaying a button, or volunteering for a political cause. Protest actions were less common as less than onefifth of the students went to a demonstration and roughly 1 in 20 students participated in civil disobedience. Although the amount of activism may not be as high as desired, the students in the sample were at least twice as active as the general U.S. population for every item except for Making a Financial Contribution (Barnes, 1999).

This study ran four ordinary least squares (OLS) regressions. Each regression used the full model when estimating the associations for doing insider and outsider behaviors. Respondents were divided into liberal and conservative aggregates because political ideologies may alter the effects of different independent variables (Hamilton \& Fauri, 2001). In sum, 73 students identified themselves as left or liberal, and 52 students considered themselves middle-of-the-road $(n=32)$ or conservative $(n=20)$.

\section{TABLE 1. Univariate Statistics for Electoral and Protest Behaviors of Liberal and Conservative Social Work Students}

\begin{tabular}{lccc}
\hline Item & $\boldsymbol{n}$ & $\%$ & Mean \\
\hline Sign a petition & 95 & 76 & \\
Write a letter & 42 & 34 \\
Display a political button & 35 & 27 \\
Office help for a political cause & 26 & 22 \\
Financial contribution to political candidate & 15 & 12 & \\
Electoral scale & & & \\
Attend a lawful demonstration & 21 & 17 & \\
Participate in civil disobedience & 5 & 4 & 0.21 \\
Protest scale & & & \\
\hline
\end{tabular}


As with any regression, an OLS deciphers the direct association for each variable when controlling for the influence of the other independent variables (standardized coefficients), and it discerns the cumulative amount of variance explained by the entire model $\left(R^{2}\right)$. As expected, the data met the requirements for this analysis because the dependent variable had an interval level of measurement and the sample lacked multicollinearity and heteroskedasticity.

Table 2 presents the associations among the 12 independent variables and the 2 dependent variables for each student subgroup. Some clear patterns emerged when examining the predictive capacities of the model. First, the entire model was relatively robust when predicting different kinds of activism. In each equation, the overall effects of the independent variables displayed significant $f$-scores $(3.63-6.37, p<.001)$. Moreover, the cumulative effects of the 12 variables accounted for at least $26.6 \%$ of the variance in the regression for each form of political expressions (one variable reached .412). Although this set of variables fared well for

TABLE 2. Regressions of Electoral and Protest Behaviors Among Liberal and Conservative Social Work Students $(N=125)$

\begin{tabular}{|c|c|c|c|c|}
\hline \multirow[b]{2}{*}{ Variable name } & \multicolumn{2}{|c|}{ Liberal students } & \multicolumn{2}{|c|}{ Conservative students } \\
\hline & Electoral & Protest & Electoral & Protest \\
\hline \multicolumn{5}{|l|}{ Personal qualities } \\
\hline Sex (female) & -.015 & -.095 & -.111 & $-.383^{* *}$ \\
\hline Single & .045 & .071 & -.176 & -.041 \\
\hline Race (White) & .005 & .053 & $.201^{*}$ & .091 \\
\hline Rural background & -.069 & $-.184^{*}$ & -.148 & -.058 \\
\hline Family income & .076 & .088 & .009 & .108 \\
\hline Education level & .079 & .124 & .044 & .031 \\
\hline \multicolumn{5}{|l|}{ Mobilizing structures } \\
\hline Liberal mother & .031 & .125 & -.020 & -.034 \\
\hline Activist friends & .148 & .013 & .080 & .115 \\
\hline Activist network & $.372^{* * *}$ & $.436^{* * *}$ & $.352^{* *}$ & $.255^{*}$ \\
\hline \multicolumn{5}{|l|}{ Collective action frames } \\
\hline Liberal injustice frame & .140 & $.288^{* *}$ & -.021 & $-.247^{* *}$ \\
\hline Activist identity & $.186^{*}$ & $.169^{*}$ & .041 & $.216^{*}$ \\
\hline Perceived tactics efficacy & $.182^{*}$ & .028 & $.430^{* * *}$ & .102 \\
\hline$n$ & 73 & 73 & 52 & 52 \\
\hline Adjusted $R^{2}$ & .266 & .412 & .317 & .394 \\
\hline$f$-score & $3.77^{* * *}$ & $6.37^{* * *}$ & $3.63^{* * *}$ & $4.36^{* * *}$ \\
\hline
\end{tabular}

Note. Cell scores are standardized beta coefficients $(\beta)$.

${ }^{*} p<.05 .{ }^{* *} p<.01 .{ }^{* *} p<.001$. 
both liberal and conservative students, the complete model was somewhat more adept at predicting outsider practices for both subgroupings (e.g., for liberal students the adjusted $R^{2}$ grew from .226 to .412 when comparing electoral and protest activities, whereas the conservative students saw an increase of .317 to .394).

When exploring the significance for specific variables, some clear trends exist. In starting with the strongest predictor, the mobilizing factor of activist networks was the only one to remain important throughout every regression. In presenting beta coefficients between .436 and .255 , activist networks repeatedly offered the highest associations $(p<.001$ to $p<.05)$. Even with this consistency, the predictive capabilities of activist networks wavered a bit because they garnered slightly lower associations with the more conservative students in this sample ( $\beta$ fell from .372 and .436 for the liberals to .352 and .255 for the conservatives).

Another set of variables saw their importance altered by the conditions of the regression. In presenting a relatively stable predictor, the concept of activist identities was significant for three of the four regressions. The internalization of personal commitment to social justice was a significant antecedent for the electoral activities of liberals and the protest tendencies for both samples ( $\beta$ ranged from .216 to $.169, p<.05$ ). However, these betas were not remarkably high and were not significant for the electoral deeds of conservatives. Two other collective action frames were frequently significant for either insider or outsider frames. Injustice frames were irrelevant for orthodox politics but consistently perti- nent to matters of protests and street politics ( $\beta$ fell between .288 and .247, $p<.01$ ). Liberal students were more likely to embrace extrainstitutional techniques when they internalized a liberal injustice frame on family dynamics, sexual minorities, and antipoverty programs. On the other hand, conservative students who expressed stronger objections to liberal critiques were more inclined to protest on the behalf of conservative social causes. Questions of tactical efficacy were only pertinent to the electoral practices of respondents. The sense that petitions and protests can produce societal changes was extremely crucial to the electoral participation of conservatives $(\beta=.430, p<.001)$, but it also forecast such actions among liberals $(\beta=.182, p<.01)$. Conversely, questions of collective potency did not seem to matter as to whether respondents went to a demonstration or engaged in civil disobedience. Finally, three demographic factors occasionally registered statistical significance. Although female respondents often refrained from all sorts of political actions, this factor was critical only in the protest actions of conservatives $(\beta=.383, p<.05)$. Being from a rural background also dampened political participation, but this factor only seemed to significantly matter among the tendency to protest among liberals $(\beta=.184, p<.05)$. Persons of color also were less active than their White counterparts, but this difference only found significance for the electoral measures of conservatives $(\beta=.201, p<.05)$.

In moving to the weakest factors, some variables were never able to offer unique contributions to the regressions. The demographic factors of marital status, family income, and educational level were never able to reject the 
null. This suggests that the unequal distribution of resources was not a crucial predictor of which students engaged in activism. Two of the mobilizing factors also offered little repercussions. Although being raised by liberal mothers slightly increased or decreased the political actions of their liberal and conservative offspring, this familial socialization variable was of little importance. Befriending people who valued and praised political activism also had negligible effects. That is, general liberalism among friends did not inspire greater activism for conservatives or liberals.

\section{Limitations}

As with any study, this research design is not without possible shortcomings. Without data on graduate students, it is impossible to know how these findings translate to MSW or PhD students. The smaller sample size makes it more difficult to reject the null and there might be sampling error as to which sorts of professors distributed the surveys in their classes (the response rate from professors was low). It is also possible that data collected in 2000 would not perfectly fit the practices of students who attended college after George W. Bush's "War on Terrorism" or the presidential election of Barack Obama. The crosssectional design also presents some disadvantages. Problems of temporal ordering may be lurking because the perceptions of collective efficacy, the acceptance of activist identities, and the framing of social practices can all be altered by earlier experiences of political activism.

Concerns over survey construction may also appear because items can fall prey to issues of vague terms, social desirability, and overdemanding recall. When discussing a lack of clarity, respondents may not always agree on the meaning of terms such as liberal or conservative, or they may not be able to guess the political inclinations of their friends or mothers. With regard to factual matters, respondents may be unaware of their family finances and forget if they have been asked to join a political event. Some may argue that the closed-ended responses for the political actions are a little restrictive. The simple "yes" or "no" answers for each item ignores some of the variability in behaviors (e.g., a student may have gone to a hundred protests whereas another could have attended a single demonstration). The emphasis on direct political actions also ignores some of the political actions that social workers do. For example, this study fails to address actions such as creating social justice groups, advocating for change within an agency, testifying at public hearings, or trying to empower disenfranchised populations (Dietz Domanski, 1998).

The way variables were defined may influence these findings as well. Injustice frames may have produced different results if new social problems were added to the scale. Although grievances with welfare policies, traditional family structures, and heterosexism fueled protest activities, it is possible that anger toward other inequities could be important as well (e.g., sexual harassment, ageism, racism, environmental degradation, deindustrialization, war).

\section{Discussion}

By creating a theoretical model, this analysis synthesized the insights of resource, framing, and mobilization theories of political partici- 
pation. Although researchers have tested similar models among other professional populations, this is not true among studies of current and future social workers (for an exception, see Ritter, 2008).

In sum, the mobilization and framing theories supplied the best predictor variables of activist behavior. The mobilizing factor of activist networks provided the strongest association in every regression. In confirming microstructural theories of activism, political participation increased when students received an interpersonal request to join a political cause. This finding held for both types of activism and every political stripe of students. On the other hand, activist tendencies seemed indifferent to the presence of liberal mothers and activist friends. Consequently, political activism does not appear to be simply a matter of passive social modeling. Neither liberal nor conservative students were more likely to be political when they shared or challenged the political values of college peers or mothers. Instead, activism developed more frequently when students had access to social networks that intentionally tried to foster activism (especially those networks that combined practical logistical information with verbal pleas to join that event). In fact, being involved in these activist networks may be a cornerstone to activism because the coefficients for this variable easily surpassed the scores in all of the framing variables. This suggests that conversations with able recruiters may have been inspirational enough to motivate activism even if the person did not have personal values that fully aligned with the goals of the political campaign. Moreover, with some framing variables occasionally meeting significance, one can assume that students often fail to act on their political sentiments until they personally meet an informal recruiter for social causes.

The framing variables received mixed results. These data suggest that different forms of activism were predicated on specific types of perceptions. In most cases, embracing an activist identity facilitated greater political participation. Conservatives and liberals alike were more likely to join demonstrations and engage in civil disobedience when they felt morally obliged to struggle for social justice through political means. The internalization of such ethics also fostered greater electoral engagement among liberals, but not conservatives. This suggests that desire to "do the right thing" and "live up to social justice ideals" was integral to student activism.

The influence of injustice frames was even more conditional. Liberal slants on traditional family values and social welfare policies never had a bearing on electoral activism. Conversely, involvement in protests and confrontational politics seemed connected to the perceived legitimacy of the status quo. In essence, conservative students attended more rallies and did civil disobedience when they unequivocally endorsed the tenor of recent welfare reforms, compulsory heterosexuality, and traditional family values. Moreover, the liberal students who fully repudiated such practices were more likely to protest than the liberal students who were more equivocal on such matters. The heightened importance of injustice frames made some sense because liberal and conservatives alike resorted to protests and confrontational actions only after they were convinced that the system needed 
more radical change and that electoral mechanisms seemed unresponsive to the demands of radical challengers.

Perceptions of collective efficacy mattered only to electoral endeavors. Students were more resigned to skip electoral politics when they thought the government was unresponsive to citizen demands. Conversely, doing outsider politics was not connected to the anticipated power of challengers. This suggests that electoral activism was linked to the reflections of the likelihood that a challenging group could produce a tangible payoff (assuming the payoff is creating change in a reluctant opponent). However, use of outsider politics seemed less dependent on expectations of external success. Instead, social movement participation seemed mostly connected to interpretations of societal wrongdoings, an internalization of protest norms, and access to recruitment networks (the payoff of activism was in the intrinsic benefits of being moral or gaining the approval of peers).

This article refutes the major premises of the socioeconomic model of political participation. Family income and the educational variables did not differentiate either the electoral or protest inclinations of conservative or liberal social work students. This lack of SES effects could be due to the unique characteristics of students in BSW programs. When compared to noncollegiate populations, undergraduate students have truncated income and educational distributions (e.g., the range was smaller because students were not full-time employees, and poor young adults attended college less often than wealthier peers). Moreover, income homogeneity may be more pronounced in BSW programs because these pro- grams often attract more poor and workingclass students (Caputo, 2004; Goyette \& Mullen, 2006).

Other social statuses were mostly inconsequential to the activist tendencies of respondents. Marital status never was significant. Perhaps this result was valid, yet most students, due to their ages, had not transitioned into either a marriage or divorce. Although rural students were generally disinclined to be involved in politics, the rural-urban divide was significant only for the protest actions of liberals. Similarly, the gender gap was negligible in most cases and mattered only when discussing the protesting activities of conservative students (traditionalist woman were less likely to protest than traditionalist men). It appears that conventional precepts of "women staying out of politics" were irrelevant for self-defined liberals but more important when addressing confrontational politics for conservatives. Racial identities were also only predictive in conservative circles. Liberal students of color were not inclined to join insider or outsider political events whereas traditionalist White students engaged in electoral activism more frequently than conservative people of color.

\section{Implications for Social Work Education}

With injustice frames being essential to protest activities, it is clear that social work programs should try to reveal the discriminatory and exploitative nature of many U.S. institutions (be it systematic sexism, racism, classism, heteronormativity, ageism, etc.). Moreover, there was evidence that students were more politically active after they took a class on hetero- 
sexism (Stake \& Hoffman, 2001), homophobia (Van Soest, 1996), racism (Van Soest, 1996), or any form of oppression (Astin, 1993, Beaumont, Colby, Ehrlich, \& Torney-Purta, 2006; Van Voorhis \& Hostetter, 2006; Rocha, 2000). Similarly, with activist identities being important in most cases, it is clear that professors must reveal the connections between client well-being and injustices in families, agencies, and political arenas. Likewise, educators must try to convince students that politics is not a "spectator sport"; that is, social work ethics requires involvement in political struggles. Moreover, educators should develop assignments and exercises that offer opportunities in advocacy practice. Some of these assignments can be classroom experiences of speaking at a mock congressional hearing, developing an imaginary media campaign, or planning a community meeting (Hoeffer, 1999; Keller, Whittaker, \& Burke, 2001). Equally important, students should be given an opportunity to have firsthand experiences in meeting governmental officials, attending political meetings, knocking on doors, chanting at protests, or doing some grassroots fundraising (see Fisher, 1995; Haynes \& Mickelson, 1997; Hull, 1987). In fact, some studies argue that political activism among students increased after colleges offered policy practice experiences outside of the classroom (Anderson \& Harris, 2005; Rocha, 2000; Sather, Weitz, \& Carlson, 2007). Finally, undergraduate social work programs can modify their curriculum. Programs can augment their policy classes by providing more instruction on social action, connecting students to issue-based advocacy groups, and offering greater access to political field practicums (Wolk, Pray, Weismiller, and Dempsey, 1996, estimated that less then $20 \%$ of BSW programs offer field practice in electoral politics and policy advocacy). Although these programs will not convert every student into a full-fledged activist, such efforts will probably lessen the widespread complaint that social work programs do an inadequate job of preparing students for policy practice (Ritter, 2008; Wolk et al., 1996).

\section{References}

Abramowitz, M. (1998). Social work and social reform. Social Work, 43, 512-526. doi:10.1093/sw/43.6.512

Anderson, D. K., \& Harris, B. M. (2005). Teaching social welfare policy. Journal of Social Work Education, 41, 511-526. doi:10.5175/JSWE.2005.200303120

Andrews, A. B. (1998). An exploratory study of political attitudes and acts among child and family service workers. Children and Youth Services Review, 20, 435-461. doi:10.1016/S0190-7409(98)00016-4

Ashmore, R., Deaux, K., \& McLaughlin-Volpe, T. (2004). An organizing framework for collective identity. Psychological Bulletin, 130, 80-114. doi:10.1037/0033-2909.130.1.80

Astin, A. (1993). What Matters in College? San Diego, CA: Jossey-Bass.

Aviram, U., \& Katan, J. (1991). Professional preferences of social workers. International Social Work, 34, 37-55. 
Barkan, S., Cohn, S., \& Whitaker, W. (1995). Beyond recruitment: Predictors of differential participation in a national antihunger organization. Sociological Forum, 10, 113-134. doi: $10.2307 / \mathrm{j} 100768$

Barnes, S. (1999). Political participation. In J. P. Robinson, P. Shaver, \& L. Wrightsman (Eds.), Measures of political attitudes (pp. 737-801). San Diego, CA: Academic Press.

Barnes, S., \& Kaase, M. (1979). Political action. Ann Arbor, MI: Inter-University Consortium for Political and Social Research.

Bean, C. (1991). Participation and political protest. Political Behavior, 13, 251-288.

Beaumont, E., Colby, A., Ehrlich, T., \& Torney-Purta, J. (2006). Promoting political competence and engagement in college students. Journal of Political Science Education, 2, 249-270. doi:10.1080/15512160600840467

Beyerlein, K., \& Andrews, K. T. (2008). Black voting during the civil rights movement. Social Forces, 87, 65-93.

Brady, H. E., Verba, S., \& Scholzman, K. L. (1995). Beyond SES: A resource model of political participation. The American Political Science Review, 89, 271-294.

Butler, A. C. (1990). A reevalution of social work student's career choices. Journal of Social Work Education, 26, 45-56.

Caputo, R. K. (2004). Professional studies vs. liberal arts \& sciences: Family background, Head Start participation, and high school curriculum as predictors of college major. Race, Gender \& Class, 11, 112-126.

Chorn-Dunham, C., \& Bengston, V. (1992). The long-term effects of political activism on intergenerational relations. Youth and Society, 24, 31-51. doi:10.1177/0044118X92024001002

Chui, E., \& Gray, M. (2004). The political activities of social workers in the context of changing roles and political transition in Hong Kong. International Journal of Social Welfare, 13, 170-180. doi:10.1111/j.1369-6866.2004.00310.x

Cole, E., Zucker, A., \& Ostrove, J. (1998). Political participation and feminist consciousness among woman activists of the 1960's. Political Psychology, 19, 349-371. doi:10.1111/j.1471-6402.2010.01600.x

Council on Social Work Education. (2001). Education policy and accreditation standards. Alexandia, VA: Author.

Dey, E. (1997). Undergraduate political attitudes. Journal of Higher Education, 68, 398-413.

Dietz Domanski, M. (1998). Prototypes of social work political participation. Social Work, 43, 156-167. doi:10.1093/sw/43.2.156

Dolan, K. (1995). Attitude, behaviors, and influences of the family. Political Behavior, 17, 231-264. doi:10.1007/BF01498596

Dudziak, S., \& Coates, J. (2004). Social worker participation in policy practice and political activity. Canadian Journal of Social Policy, 54, 79-96.

Eckberg, D. L. (1988). The physicians anti-abortion campaign and the social bases of moral reform participation. Social Forces, 67, 379-396. doi:10.1093/sf/67.2.378 
Ezell, M. (1993). The political activism of social workers: A post-Reagan update. Journal of Sociology and Social Welfare, 20(4), 81-97.

Fahs, B. (2007). Second shifts and political awakenings: Divorce and the political socialization of middle aged women. Journal of Divorce and Remarriage, 47, 43-66. doi:10.1300/J087v47n03_03

Finkel, S., \& Muller, E. N. (1998). Rational choice and collective political action. American Political Science Review, 92, 37-50. Retrieved from http://www.jstor.org/stable/2585927 Fisher, R. (1995). Political social work. Journal of Social Work Education, 31, 194-203.

Gamson, W. (1992). The social psychology of collective action. In A. D. Morris \& C. M. Mueller (Eds.), Frontiers of social movement theory (pp. 53-76). New Haven, CT: Yale University Press.

Gitlin, T. (1980). The whole world is watching: Mass media in the making and unmaking of the new left. Berkeley, CA: University of California Press.

Goyette, K. A., \& Mullen, A. L. (2006). Who studies the arts and sciences? Social background and the choice and consequences of undergraduate field of study. Journal of Higher Education, 77, 98-538. doi:10.1353/jhe.2006.0020

Gray, M., Collet van Rooyen, C., Rennie, G., \& Gaha, J. (2002). The political participation of social workers: A comparative study. International Journal of Social Welfare, 11, 99-110. doi:10.1111/1468-2397.00204

Hamilton, D., \& Fauri, D. (2001). Social workers' political participation. Journal of Social Work Education, 37, 321-331.

Hanson, J. G., \& McCullagh, J. G. (1995). Career choice factors for BSW students. Journal of Social Work Education, 31, 28-37.

Haynes, K., \& Mickelson, J. (1997). Affecting change: Social workers in the political arena. New York, NY: Longman.

Hoeffer, R. (1999). The social work and politics initiative. Journal of Community Practice, 6 , 71-87. doi:10.1300/J125v06n03_04

Hritzuk, N., \& Park, D. (2000). The question of Latino participation: From an SES to social structural explanation. Social Science Quarterly, 81, 152-177.

Hull, G. H. (1987). Joining together: A faculty-student experience in political campaigning. Journal of Social Work Education, 23, 37-43.

Keller, T. E., Whittaker, J. K., \& Burke, T. K. (2001). Student debates in policy classes. Journal of Social Work Education, 37, 343-355.

Kelly, C., \& Breilinger, S. (1995). Identity and injustice: Exploring women's participation in collective action. Journal of Community and Applied Social Psychology, 5, 41-57. doi:10.1002/casp.2450050104

Kingston, P., \& Finkel, S. (1987). Is there a marriage gap in politics? Journal of Marriage and the Family, 49, 57-64.

Klandermans, B. (1997). The social psychology of protest. New York, NY: Blackwell Publishers. 
Leighley, J. E., \& Nagler, J. (1992). Individual and systemic influences on turnout: Who votes? Journal of Politics, 54, 718-740. doi:10.2307/j100248

Leighley, J. E., \& Vedlitz, A. (1999). Race, ethnicity, and political participation. Journal of Politics, 61, 1092-1114. doi:10.2307/j100248

Lim, C. (2008). Social networks and political participation: How do networks matter? Social Forces, 87, 961-982. doi:10.13253/sof.0.0143

Mary, N. (2001). Political activism of social work educators. Journal of Community Practice, 9, 1-20. doi:10.1300/J125v09n04_01

McAdam, D., \& Paulsen, R. (1993). Specifying the relationship between social ties and activism. American Journal of Sociology, 99, 640-667. doi:10.2307/j100067

McCarthy, J. D. (1996). Mobilizing structures: Constraints and opportunities in adopting, adapting and inventing. In D. McAdam, J. D. McCarthy, \& M. N. Zald (Eds.), Comparative perspectives on social movements: Political opportunities, mobilizing structures, and cultural framings (pp. 141-151). Cambridge, England: Cambridge University Press.

Mullalay, R. (1993). Structural social work: Ideology, theory and practice. Toronto, Canada: McClelland and Stewart Press.

National Association of Social Workers. (2008). Code of ethics. Washington, DC: Author.

Nepstad, S. E., \& Smith, C. (1999). Rethinking recruitment to high risk activism. Mobilization, 4, 25-40.

Oliver, P. (1984). If you don't do it, nobody will: Active and token contributions to local collective action. American Sociological Review, 49, 601-610.

Opp, K. (1990). Postmaterialisms, collective action and political protest. American Journal of Political Science, 34, 212-235. doi:10.2307/j100487

Parker, M., \& Sherraden, M. (1992). Electoral participation of social workers. New England Journal of Human Services, 11, 23-28.

Passy, F. (2001). Socialization, connection, and the structure/agency gap: A specification of the impact of networks on participation in social movements. Mobilization, 6, 173-192.

Paulsen, R. (1994). How stratification affects protest participation of young adults. Sociological Perspectives, 37, 635-644. Retrieved from http://www.jstor.org/stable/1389282

Pawlak, E., \& Flynn, P. (1990). Executive director's political activities. Social Work, 35, 307-312.

Polletta, F., \& Jasper, J. M. (2001). Collective identity and social movements. Annual Review of Sociology, 27, 283-305. doi:10.2307/j100663

Reeser, L. (1992). Professional role orientation and social activism. Journal of Sociology and Social Welfare, 19, 79-84.

Ritter, J. A. (2008). A national study predicting social workers political participation: The role of resources, psychological engagement and recruitment networks. Social Work, 53, 347-357. doi:10.1093/sw/53.4.347

Rocha, C. (2000). Evaluating experiential teaching methods in a policy practice course. Journal of Social Work Education, 36, 53-63. 
Sather, P, Weitz, W., \& Carlson, P. (2007). Engaging students in macro issues through community-based learning. Journal of Teaching in Social Work, 27, 61-79. doi:10.1300/J067v27n03_05

Schussman, A., \& Soule, S. A. (2005). Process and protest: Accounting for individual protest participation. Social Forces, 84, 1083-1108. doi:10.1353/sof.2006.0034

Simon, B., Lowry, M., Sturmer, S., Weber, U., \& Freitag, P. (1998). Collective identification and social movement participation. Journal of Personality and Social Psychology, 74, 646-658. doi:10.1037/0022-3514.74.3.646

Snow, D., \& Benford, R. (1992). Master frames and cycles of protest. In A. Morris \& C. Mueller (Eds.), Frontiers in social movement theory (pp. 133-155). New Haven, CT: Yale University Press.

Specht, H., \& Courtney, M. E. (1993). Unfaithful angels: How social work has abandoned its mission. New York, NY: Simon and Schuster.

Stake, J. E., \& Hoffman, F. L. (2001). Changes in student social attitudes, activism and personal confidence in higher education. American Educational Research Journal, 38, 411-436. doi:10.3102/00028312038002411

Stoker, L., \& Jennings, M. K. (1995). Life-cycle transitions and political participation: The case of marriage. The American Political Science Review, 89, 421-433. Retrieved from http://www.jstor.org/stable/2082435

Swank, E. (1994). Shall we overcome? The sense of power among Gulf War protestors. Critical Sociology, 20, 31-51. doi: 10.1177/089692059402000102

Swank, E., \& Fahs, B. (2011). Students for peace: Contextual and framing motivations for antiwar activism. Journal of Sociology \& Social Welfare, 38, 111-136.

Tate, K. (1991). Black political participation in the 1984 and 1988 presidential elections. American Political Science Review, 85, 1159-1176. doi:10.2307/j100077

Van Soest, D. (1996). The impact of social work education on student attitudes and behavior concerning oppression. Journal of Social Work Education, 32, 191-202.

Van Voorhis, R., \& Hostetter, C. (2006). The impact of MSW education on social worker empowerment and commitment to client empowerment through social justice advocacy. Journal of Social Work Education, 42, 105-121. doi:10.5175/JSWE.2006.200303147

Wallace, M., \& Jenkins, J. C. (1995). New class, postindustrialism, and neocorporatism: Three images of protest in Western societies. In J. C. Jenkins \& B. Klandermans (Eds.), The politics of social protest (pp. 96-137). Minneapolis, MN: University of Minnesota Press.

Weiss, I. (2003). Social work students and social change. International Journal of Social Welfare, 12, 132-141. doi:10.1111/1468-2397.00251

Weiss, I., \& Kaufman, R. (2006). Educating for social action. Journal of Policy Practice, 5, 5-28. doi:10.1300/J508v05n01_02

Wolk, J. (1981). Are social workers politically active? Social Work, 26, 283-288. 
Wolk, J., Pray, J., Weismiller, T., \& Dempsey, D. (1996). Political practica. Journal of Social Work Education, 32, 91-100.

Wood J., \& Ng, W. (1980). Socialization and student activism. Research in Social Movements, Conflicts, and Change, 3, 21-43.

Accepted: $07 / 11$

Eric W. Swank is associate professor at Morehead State University.

Address correspondence to Eric W. Swank, Department of Sociology, Social Work and Criminology, Morehead State University, Morehead, KY 40351; e-mail: e.swank@morehead-st.edu.

\section{UISCISChool of Social Worts}

\section{Open Rank Tenure-Track Faculty Positions}

\section{A Three-Year Recruiting Announcement}

The School of Social Work at the University of Southern California has adopted a three-year strategic plan for recruitment of new faculty. Applications are welcome for a starting date anytime up until fall 2014. We encourage senior faculty to submit joint applications with highly accomplished junior mentees. About the USC School of Social Work: The School is a vibrant environment, with six major areas of federally sponsored research, nearly 2000 graduate students in 38 states, and a highly productive, globally oriented faculty. We are distinguished by our commitment to science in social work, diversity, interdisciplinary perspectives, and translational research. Qualifications Sought: For all ranks, a PhD in social work, social welfare or a related field is required. The School seeks scholars who publish and communicate in venues with high visibility, have strong potential for external research support, and wish to work in a collegial context. We are especially interested in candidates with expertise in the following areas: social program administration, health policy, child development and children's services, cost-effectiveness research, behavioral health, and homelessness. Because Los Angeles is one of the most diverse metropolitan area in the United States, we seek faculty who have strong scholarship profiles involving Latina, Asian-Pacific Islander, and/or African-American populations. Applicants should also have global relationships or be willing to build these networks, preferably in Latir American and Asia. Application Procedure: Please submit a letter of application outlining teaching and research interests, a curriculum vita, two samples of scholarly writing, evidence of teaching excellence, names and contact information of three references and three recommendation letters.

Online applications are required. Please apply at: https://jobs.usc.edu/applicants/Central?quickFind $=61509$.

Please mail your recommendation letters to: Maryalice Jordan-Marsh, Chair, Faculty Search Committee USC School of Social Work, 669 W. 34th Street, MRF 214, Los Angeles, CA 90089-0411

Review of applications will be carrieć out continuously over the next three years until all positions are filled. Salary and benefit packages are highly competitive.

To learn more about our school, please visit our website at: www.usc.edu/socialwork The University of Southem California is an affirmative action, equal opportunity empioyer and does not discriminate on the basis of race, color, national original, sexual orientation, gender. age disability, veteran status, political orientation or other characteristic: 
Copyright of Journal of Social Work Education is the property of Council on Social Work Education and its content may not be copied or emailed to multiple sites or posted to a listserv without the copyright holder's express written permission. However, users may print, download, or email articles for individual use. 